\title{
Hakikat Tuhan: Kajian Pemikiran Islam dalam Falsafah Jawa
}

\section{Syarifah Wardah el Firdausy}

University Kebangsaan Malaysia

\begin{abstract}
Islamic thought in the Javanese philosophy of the concept of God begins with the existence of three continuities between (I) the background of Islamization in Indonesia, through cultural approaches, (2) philosophical phrases in the Javanese philosophy as a part of the characteristic Javanese literary works that are educational (didactic) and sublime (piwulang), and (3) the similarity between the concept of tri hita wacana means harmonious relationship of man with God (habluminallah) in Islamic teachings related to the concept of insan kamil. This study uses qualitative methods based on literature study data and descriptive analysis as a whole (integral). The results obtained from this study is the similarity of thinking between the philosophical expressions of Java in the Javanese philosophy with Islamic thought in the verses of the Qur'an as part of the teachings of Islam in understanding the three concepts of the nature of God that is (I) the concept of tan kena kinaya gapa means that God cannot be imagined circumstances and forms, but the absolute power, (2) the concept of GustiAllah orah sare means God is not sleeping and always awake in every period; Understanding of the concept raises an attitude of being cautious in acting, acting, and fully aware of God's supervision, and (3) the concept of sangkan paran which has an understanding that the beginning of the creation of man and the universe comes from God (sangkan) and the end of creation Man and the universe will return to God (paran).
\end{abstract}

\begin{abstract}
Abstrak
Pemikiran Islam dalam falsafah Jawa terkait konsep Tuhan berawal dari adanya tiga kesinambungan antara: (I) latar belakang Islamisasi di Nusantara, melalui pendekatan kultural, (2) ungkapan-ungkapan filosofis dalam falsafah Jawa sebagai bagian dari ciri khas karya sastra Jawa yang bersifat mendidik (didaktis) dan luhur (piwulang), dan (3) kesamaan antara konsep hubungan harmonis manusia dengan Tuhan dalam konsep tri hita wacana dengan ajaran hubungan baik antara manusia dengan Tuhan (habluminallah) dalam ajaran Islam terkait konsep insan kamil. Kajian ini menggunakan metode kualitatif berdasarkan data studi literatur dan analisis deskriptif secara menyeluruh (integral). Hasil yang diperoleh dari kajian ini yaitu adanya kesamaan alur berpikir antara ungkapan-ungkapan filosofis Jawa dalam falsafah Jawa dengan pemikiran Islam dalam ayat Alquran sebagai bagian dari ajaran Islam
\end{abstract}


dalam memahami tiga konsep hakikat Tuhan yaitu (I) konsep tan kena kinaya gapa yang berarti Tuhan tidak dapat dibayangkan keadaan dan wujudnya, tetapi mutlak kekuasaannya, (2) konsep Gusti Allah orah sare berarti Tuhan tidak tidur dan senantiasa terjaga di setiap masa; pemahaman terhadap konsep tersebut menimbulkan sikap untuk selalu berhati-hati dalam bertindak, bertingkah laku, serta sepenuhnya sadar akan pengawasan Tuhan, dan (3) konsep sangkan paran yang memiliki pemahaman bahwa awal penciptaan manusia dan alam semesta berasal dari Tuhan (sangkan) dan akhir penciptaan manusia dan alam semesta akan kembali pada Tuhan (paran).

Keywords: Javanese philosophy, the essence of God, habluminallah, Islamic thought DOI: 10.22515/shahih.v2i1.684

\section{Pendahuluan}

Adanya pemikiran Islam dalam falsafah Jawa tidak dapat dilepaskan dari sejarah masuknya Islam di tanah Jawa. Sejarah mencatat, Islam telah masuk ke Nusantara sejak pertengahan abad ke-7 Masehi yaitu pada saat Ratu Simha berkuasa di Kerajaan Kalingga sebagaimana diberitakan sumber-sumber Cina dari Dinasti Tang (Quswandhi, 2008, pp. xxviii-xxix). Kedatangan Islam pada abad ke-7 Masehi tersebut, belum dapat diterima secara luas di Nusantara terutama di tanah Jawa dan baru dapat diterima secara luas pada sekitar pertengahan abad ke-15 di era kepemimpinan Wali Songo ${ }^{1}$ (Sunyoto, 2012, p. 47).

Di antara beberapa teori masuknya Islam di Nusantara, utamanya di Jawa terdapat teori yang menyebutkan bahwa Islam dapat diterima di Nusantara berasal dari Islam Champa. Islam Champa yaitu keberadaan Wali Songo sebagai pensyiar Islam yang ajarannya diterima di Nusantara, berawal dari kedatangan dua bersaudara putra Syeikh Ibrahim Asmarakandi yang berasal dari negeri Champa ke Jawa sekitar tahun 1140 Masehi sebagai tonggak dimulainya proses dakwah Islam di Nusantara. Dua bersaudara dari negeri Champa tersebut yaitu Raden Ali Murtadho atau dikenal dengan nama Sunan Gresik dan Raden Rahmat atau yang dikenal dengan Sunan Ampel. Kedatangan dua bersaudara dari negeri Champa tersebut juga tertulis dalam beberapa kitab yaitu Babad Tanah Djawi, Serat Kandha, Babad Ngampeldenta, Babad Risaking Majapahit, Serat Kandhaning Ringgit Purwa, Babad Tjirebon, Sadjarah Banten, dan Pustaka Kretabhumi. Setelah datangnya kedua saudara dari Champa tersebut akhirnya Islam mulai dianut oleh kalangan para pemimpin, yaitu dalam kalangan keluarga raja Majapahit yang selanjutnya dianut oleh masyarakat pribumi secara luas (Sunyoto, 2012, pp. 337-338 ).

1 Menurut (Salam, 1960, p. 109) dalam Sekitar Wali Songo, kata Wali Songo merupakan gabungan dari dua kata yaitu wali dan songo. Kata wali berasal dari bahasa Arab, satu singkatan dari kata waliyullah yang berarti orang yang mencintai dan dicintai Allah. Sedangkan kata songo berasal dari bahasa Jawa yang bererti sembilan. Jadi, wali songo bererti wali yang berjumlah sembilan, yaitu sembilan orang yang mencintai dan dicintai Allah. Mereka dipandang sebagai ketua mubaligh Islam yang bertugas mengislamkan daerah-daerah dan penduduk yang belum memeluk Islam di Jawa. Sembilan wali (Wali Songo) tersebut adalah Sunan Ampel, Sunan Maulana Malik Ibrahim, Sunan Giri, Sunan Drajat, Sunan Bonang, Sunan Muria, Sunan Kudus, Sunan Kalijaga, dan Sunan Gunung Jati. 


\section{Peran Wali Songo: Islamisasi Melalui Pendekatan Tasawuf dan Budaya}

Sebagaimana telah disampaikan di awal, yaitu Islam telah masuk ke Nusantara pada abad ke-7 Masehi yang ditandai dengan hadirnya pedagang-pedagang dari Arab dan Persia. Sementara itu Islam justru baru dapat diterima secara menyeluruh yaitu pada abad ke-15 Masehi di era dakwah Wali Songo. Hal tersebut bermakna bahwa terdapat rentang waktu sekitar delapan abad sejak masuknya Islam ke Nusantara, Islam belum dianut secara luas oleh penduduk pribumi di Nusantara.

Wali Songo dalam berdakwah di Nusantara khususnya di Jawa menggunakan cara-cara damai yang menunjukkan pada usaha-usaha penyampaian dakwah Islam melalui prinsip mau'izah al-hasanah waja dilhum bi al-latihiyaahsan, yaitu sebuah metode penyampaian ajaran Islam melalui cara dan tutur bahasa yang baik.

Sebagaimana lazimnya nilai-nilai yang bersumber dari ajaran Islam, maka nilai-nilai keislaman yang dikembangkan oleh Wali Songo tersebut ditegakkan di atas asas keseimbangan dan keselarasan. Kelembutan dan toleransi ajaran sufisme yang di bawa oleh Wali Songo tersebut dapat dilihat pada nilai-nilai keislaman yang di ambil dari bahasa Arab kemudian merasuk ke dalam nilai-nilai masyarakat yang jejaknya masih terlihat dalam nilai-nilai moral yang dianut masayarakat Jawa sampai saat ini. Di antaranya seperti nilai kesabaran (shabar), keikhlasan (ikhlas), andap-ashor (tawadhu'), keadilan (adl), guyub rukun (ukhuwah), lila atau rela (ridha), kesederhanaan (wara'), nrimo (qana'ah), eling (dikir), ngalah (tawakal), pasrah (lillah) yang merujuk kepada nilai-nilai sufistik (Sunyoto, 2012, p. 378). Ajaran Islam yang dikemas oleh Wali Songo juga diajarkan dengan sederhana dan dikaitkan dengan pemahaman masyarakat setempat atau dapat dipahami dengan ajaran Islam yang dibumikan sesuai adat, budaya $^{2}$, dan kepercayaan penduduk setempat melalui proses asimilasi ${ }^{3}$ dan sinkretisme ${ }^{4}$. Pelaksanaan dakwah dengan cara tersebut memang memerlukan waktu yang lama, akan tetapi berlangsung secara damai. Melalui metode tersebut, maka unsur-unsur budaya lokal yang sudah ada sebelum Islam masuk ke Nusantara yaitu pada masa Hindu-Buddha yang dianggap sesuai dengan sendi-sendi tauhid, kemudian diserap ke dalam dakwah Islam.

Menurut James Peacock dalam Purifying the Faith (1979), Islam yang datang ke Jawa adalah Islam sufi yang dengan mudah diterima serta diserap ke dalam sinkretisme Jawa. Usaha-usaha bersifat asimilatif dan sinkretik dalam dakwah Islam Wali Songo secara teoritik maupun faktual dapat disimpulkan sangat sukar dilakukan oleh mubaligh-mubaligh penyebar

2 Pendekatan dakwah kultural yang digunakan oleh Wali Songo semakin memudahkan penerimaan Islam oleh masyarakat setempat (Mustakim, 2005, p. 27). Proses akomodasi budaya dapat dilihat pada kemampuan Islam untuk beradaptasi dengan tradisi dan adat lokal serta kemampuannya untuk tetap mempertahankan nilai-nilai utama ajaran Islam. Proses akomodasi ini dapat berjalan dengan baik kerana sifat-sifat dan sikap kaum sufi yang kompromis dan penuh kasih sayang (Azra, 2002, p. 29).

3 Asimilasi adalah penyesuaian (peleburan) sifat asli yang dimiliki dengan sifat lingkungan sekitar.

4 Sinkretisme adalah paham (aliran) baru yang merupakan perpaduan dari beberapa paham (aliran) yang berbeda untuk mencari keserasian dan keseimbangan. 
Islam sebelum era Wali Songo. Dakwah bersifat asimilatif dan sinkretik dalam dakwah Islam Wali Songo tersebut merupakan wujud wajah kaum sufi yang sangat terbuka, luwes, dan adaptif dalam menyikapi keberadaan ajaran selain Islam (Sunyoto, 2012, p. 124).

Keberadaan kitab-kitab Suluk Wujil, Primbon Bonang, Suluk Linglung, Suluk Sukarsa, Suluk Sujinah, Suluk Syaikh Malaya, Suluk Pustaka Rancang, Serat Dewa Ruci, Serat Arjuna Wiwaha Jarwa, dan Serat Cebolek menunjukkan bukti bahwa perkembangan Islam di Jawa khususnya di era Wali Songo lebih didominasi oleh paham kesufian. Serat Dewa Ruci yang dikaitkan dengan tokoh Sunan Kalijaga pada dasarnya merupakan pengembangan naskah Nawa Ruci, karya spiritual pada zaman Hindu-Buddha yang ditulis pada masa Majapahit yang kemudian dimasuki paham-paham kesufian sedemikian rupa sehingga naskah Dewa Ruci seolah-olah adalah karya baru pada zaman Islam di tanah Jawa.

Di samping naskah Dewa Ruci, bukti asimilasi lain dalam mengislamkan ajaran HinduBuddha adalah dengan cara mengubah dan menyesuaikan epos Ramayana dan Mahabharata sebuah wira cerita dari India yang turut masuk ke Nusantara saat agama Hindu masuk ke Nusantara. Dalam proses tersebut, terjadi de-dewanisasi menuju humanisasi demi tumbuhnya tauhid dalam usaha mengislamkan pakem (aturan) dalam cerita Mahabharata dan Ramayana tersebut, maka dibuatlah cerita Mahabharata dan Ramayana yang disesuaikan dengan nilainilai Islam. Usaha de-dewanisasi yang dilakukan dalam pengislaman epos Mahabharata dan Ramayana tercermin dari munculnya cerita-cerita yang berkaitan dengan kelemahan dan kekurangan dewa-dewa sebagai sesembahan manusia. Selain itu, juga kebiasaan poliandri atau memiliki suami lebih dari satu yang lazim terjadi pada tokoh-tokoh dalam kisah Mahabharata yaitu pada tokoh Dewi Drupadi, diubah sedemikian rupa seolah-olah hanya bersifat simbolik dan bahkan dikaitkan dengan cerita baru. Sedangkan cerita Ramayana juga diislamkan oleh Wali Songo menjadi Serat Rama Jarwa dengan mengganti tokoh-tokoh yang ada dalam Ramayana menjadi tokoh yang dikenal dalam cerita Islam yaitu tokoh Rama menjadi nabi Adam, tokoh Shinta sebagai istri Rama menjadi Siti Hawa, dan tokoh Rahwana yang merupakan raksasa jahat diubah menjadi iblis yang mengganggu nabi Adam dan Siti Hawa saat berada di surga.

Setelah epos Mahabharata dan Ramayana diislamkan, maka dibuatlah pakem wayang kulit dari epos Mahabharata dan Ramayana yang telah disesuaikan dari nilai-nilai hinduistik menjadi nilai-nilai Islam. Melalui kenyataan sejarah tentang keberadaan pakem atau aturan wayang kulit yang menyimpang dari naskah induknya yang asli, maka semakin jelas bahwa usaha-usaha para mubaligh Islam oleh Wali Songo, telah dilakukan perombakan budaya dan tradisi keagamaan yang ada di tengah-tengah masyarakat. Terlebih tidak hanya sekadar melalui penyesuaian pakem wayang kulit saja, legenda-legenda yang terlebih dahulu telah dikenal masyarakat, kemudian juga disesuaikan dengan akidah dan nilai-nilai keislaman, sehingga masyarakat kemudian dengan cepat menganggap bahwa cerita Mahabharata, 
Ramayana, wayang kulit, dan legenda-legenda versi Wali Songo itulah yang benar (Sunyoto, 2012, p. 368).

\section{Tradisi Islamisasi melalui Nilai-Nilai dalam Budaya dan Karya Sastra}

Kelenturan ajaran sufisme yang dibawa oleh Wali Songo sebagaimana yang telah dipaparkan di atas, terlihat jejaknya pada proses Islamisasi di Nusantara melalui jalur asimilasi dalam kehidupan sosial, budaya, seni, sastra, pendidikan, dan adat kebiasaan. Proses asimilasi budaya dan sinkretisme antara Hindu-Buddha Jawa dan Islam yang dilakukan oleh Wali Songo itulah yang pada akhirnya banyak menghasilkan berbagai jenis hasil kebudayaan yang mengagumkan. Di antaranya adalah munculnya bentuk aneka tulisan di Jawa, yaitu naskah-naskah Jawa sebagai saksi hidup pemikiran orang Jawa.

Tradisi Islamisasi melalui nilai-nilai budaya dan karya sastra yang telah dilakukan oleh Wali Songo tersebut, turut dibantu oleh raja-raja Jawa yang pandai dan mencintai karya sastra, serta para pujangga di istana keraton Jawa. Keduanya juga turut berperan dalam proses Islamisasi, khususnya melalui penulisan karya sastra Jawa. Di antara raja-raja yang pemikiran Islamnya dituangkan melalui karya sastra Jawa adalah Raja Paku Buwono III yang menulis gubahan karya sastra unggul berjudul Kakawin Arjuna Wiwaha karya Mpu Kanwa (abad XI) $)^{5}$ yang mash bernuansa Hindu-Buddha menjadi Serat Wiwaha Jarwa (17491788). Kemudian Raja Pakubuwana IV yang juga menulis karya sastra unggul berjudul Serat Wulangreh (1789-1820), dan Raja Mangku Negara IV yang juga menulis karya sastra unggul berjudul Serat Wedahatama (1809-1881). Sementara itu, pujangga istana atau pujangga keraton Jawa juga berperan besar dalam membantu proses Islamisasi yang dilakukan oleh Wali Songo, khususnya melalui penulisan karya sastra Jawa bernuansa ajaran Islam. Salah satu pujangga Jawa yang berjasa dalam mengislamkan karya sastra Jawa yaitu R. Ng.

5 Cerita Arjuna Wiwaha pada mulanya merupakan karangan Mpu Kanwa berbahasa Jawa Kawi atau Jawa Kuna. Mpu Kanwa merupakan seorang ahli syair dan falsafah yang hidup pada abad pertengahan yaitu abad XI. Pada waktu itu di Jawa Timur bertahta Raja Airlangga. Bahan-bahan asli cerita Arjuna Wiwaha, dipetik dari cerita Mahabharata parwa ke III yaitu Vana parva atau Wana parwa yang menceritakan pemusnahan Raja Raksasa Prabu Niwatakawaca. Dalam Vana parwa tersebut cerita mengenai tokoh Arjuna sebenarnya tidak tercantum di sana. Demikian pula halnya dengan cerita yang menyatakan bahwa setelah Arjuna memusnahkan Prabu Niwatakawaca ia dinobatkan sebagai Raja Karang Kawidhodaren di Suralaya. Penambahan cerita tersebut diselipkan dengan maksud menghormati Raja Airlangga yang pada waktu itu (abad ke-XI) sedang mengadakan pesta besar sehubungan dengan perkawinannya dengan Putri Sanggramawijayaharma Prasaduttunggadewi, yaitu putri Raja Sriwijaya. Pada saat cerita Arjuna Wiwaha dibuat, kerajaan Airlangga dalam keadaan perang. Maka kedudukan Arjuna dalam cerita Arjuna Wiwaha disamakan dengan kedudukan dan kewibawaan Raja Airlangga pada masa itu. Dengan demikian, cerita Arjuna Wiwaha mempunyai nilai sejarah (Sunardi, 1993, p.7 ). 
Ranggawarsita (Raden Ngabei Ranggawarsita). Perkataan raden berasal dari kata rahadian yang berarti tuanku, sedangkan ngabei berasal dari kata kabeh yang berarti semua atau menyeluruh. Oleh karena itu. gelar raden ngabei secara keseluruhan bermakna orang yang memiliki ilmu yang menyeluruh. Hal tersebut dapat dipahami manakala gelar pujangga pada zaman dahulu seperti juga gelar $M p u$, tidak hanya bermakna orang yang pandai bersastra sebagaimana makna gelar pujangga saat ini. Gelar pujangga pada zaman dahulu bermakna seseorang yang ilmunya menyeluruh, yaitu seorang yang ahli berfalsafah (filsuf), seorang yang luas ilmunya, seorang yang menguasai ilmu agama, dan juga seorang yang pandai menulis karya sastra. Pemikiran yang menyeluruh dari pujangga Jawa tersebut kemudian dituangkan dalam karya-karya sastra Jawa.

\section{Karya Sastra Jawa Bersifat Didaktis}

Berdasarkan latar belakang dan ilmu yang dimiliki oleh penulis karya sastra Jawa yaitu seorang ulama (Wali Songo), raja-raja Jawa, dan pujangga keraton Jawa tersebut, maka karya sastra Jawa dianggap sebagai karya sastra bermutu tinggi. Sebab di dalamnya tidak hanya berisi mengenai cerita hiburan semata (dongeng, cerita fiktif, dan cerita yang bersifat menghibur) melainkan karya sastra Jawa bersifat didaktis atau mendidik. Selain bersifat didaktis, karya sastra Jawa juga tidak terpisah dari ajaran-ajaran yang bersifat luhur. Di dalam ajaran-ajaran luhur tersebut mencakup nilai-nilai agama (religiusitas), falsafah (kebenaran atau logika yang mendalam), etika (kebaikan), dan estetika (keindahan).Ajaran luhur dalam karya sastra Jawa tersebut juga biasa disebut dengan karya piwulang.

Karya piwulang merupakan karya sastra yang dominan dalam sastra Jawa yang berisi tentang suatu ajaran yang mengandung nilai-nilai keluhuran moral. Karya sastra piwulang mengandung nilai-nilai rohani dan ajaran moral atau etika yang ditujukan kepada pembacanya. Hal ini merupakan sebuah bukti bahwa karya sastra Jawa bersifat didaktis atau mendidik. Karya sastra piwulang tersebut sejatinya bersumber dari nilai-nilai keagamaan atau ajaran yang berasal dari Tuhan (Munarsih, 2007, pp. iii-iv). Salah satu karya sastra Jawa yang bersifat piwulang yaitu Serat Wirid Hidayat Jati (1802-1873) karya pujangga besar R. Ng. Ranggawarsita.

\section{Keterkaitan Karya Sastra Jawa dengan Falsafah Jawa}

Berbeda dengan falsafah Barat yang dirumuskan melalui logika berpikir secara langsung dan bersifat lugas, maka falsafah Jawa justru disampaikan dalam bentuk ungkapanungkapan, renungan-renungan, berbentuk perlambangan dan kiasan yang dituliskan dalam karya sastra Jawa. Karya sastra Jawa bersifat didaktis dan disebut sebagai karya sastra piwulang karena salah satunya mengandung falsafah hidup yang mendalam. Falsafah tersebut 
mencakup pembahasan mengenai hakikat Tuhan, manusia, dan alam semesta sebagai satu kesatuan yang integral (menyeluruh) dan dikaji secara mendalam (radix).

\section{Prinsip Ngudi Kasampurnaan dalam Falsafah Jawa}

Menurut (Ciptoprawiro, 2000, p. 14) dalam bukunya yang berjudul Filsafat Jawa, falsafah Jawa berarti cinta kesempurnaan (the love of perfection) atau berusaha mencari kesempurnaan (ngudi kasampurnaan). Maka jika dirumuskan menggunakan bahasa Jawa, akan terlihat perbedaan antara falsafah Barat dengan falsafah Jawa. Apabila falsafah Barat diartikan dengan mencari kebijaksanaan (the love of wisdom), bahasa Jawa akan menyebut falsafah Barat sebagai ngudi kawicaksanaan, sedangkan falsafah Jawa sebagai ngudi kasampurnaan atau mencari kesempurnaan. Ngudi kasampurnaan atau mencari kesempurnaan berarti, manusia mencurahkan seluruh kewujudannya, baik jasmani maupun rohani untuk mencapai tujuan itu (kesempurnaan hidup).

\section{Keterkaitan Konsep Tri Hita Wacana dalam Falsafah Jawa dengan Ajaran Insan Kamil}

Jika falsafah Jawa berarti cinta kesempurnaan (the love of perfection) atau dalam bahasa Jawa disebut dengan ngudi kasampurnaan atau berusaha mencari kesempurnaan hidup (Ciptoprawiro, 2000, p. 14), maka Islam pun mengajarkan hal yang sama yaitu bagaimana menjadi manusia sempurna (insan kamil) yang senantiasa memiliki hubungan yang baik dengan Tuhan (habluminallah), dengan manusia (habluminannas), serta hubungan yang baik dengan kehidupan dan alam semesta (habluminalhayat). Ketiga hubungan baik untuk menjadi insan kamil tersebut juga selaras dengan konsep tri hita wacana dalam falsafah Jawa yaitu tiga hubungan harmonis yang menyebabkan timbulnya kebahagiaan.

Tri hita wacana bermakna hubungan yang harmonis antara manusia dengan Tuhan, hubungan harmonis antara manusia dengan manusia lainnya, dan hubungan harmonis antara manusia dengan alam semesta atau lingkungannya (Pasha, 2011, pp. 74-75).

\section{Hakikat Pemikiran dalam Falsafah Jawa}

Pengertian hakikat menurut (Departemen Pendidikan dan Kebudayaan., 1991) adalah inti sari atau dasar. Sementara pengertian hakikat menurut (Endraswara, 2012, p. 1) dalam bukunya yang berjudul Filsafat Sastra, hakikat berasal dari kata haq yang berarti kanan. Haq juga berarti benar. Oleh karena itu, secara keseluruhan, hakikat bermakna kebenaran tentang suatu hal. 
Selain itu, dalam bukunya yang berjudul Filsafat Ilmu (Endraswara, 2013, p. 97) juga menyebutkan bahwa hakikat adalah sebuah realitas atau kenyataan yang sebenarnya. Kajian mengenai hakikat ini berkaitan erat dengan kajian filsafat ilmu ontologi. Ontologi adalah the theory of being qua being (teori tentang keberadaan sebagai keberadaan), atau juga disebut sebagai studi tentang yang ada (being) secara universal. Ontologi berusaha mencari inti yang termuat dalam setiap kenyataan atau menjelaskan yang ada dalam setiap bentuknya (Endraswara, 2013, p. 98). Jadi, ontologi merupakan studi yang terdalam dari setiap hakikat kenyataan yang menjadi pijakan bagi manusia untuk berpikir kritis tentang yang ada, meliputi Tuhan, manusia, dan alam semesta. Dalam kajian ini akan dianalisis pada tiga konsep, yaitu (1) konsep tan kena kinayagapa, (2) konsep Gusti Allah orah sare, dan (3) konsep sangkan paran.

\section{Konsep Tan Kena Kinaya Gapa}

Unsur yang paling utama dalam kepercayaan manusia Jawa ialah kepercayaan bahwa adanya Tuhan. Orang Jawa menggambarkan keberadaan Tuhan dengan konsep tan kena kinaya gapa yang berarti Tuhan tidak dapat dibayangkan keadaannya. Walaupun tidak dapat dibayangkan keadaannya, tetapi manusia Jawa meyakini bahawa Tuhan itu ada. Tan kena kinaya gapa juga bermakna, manusia Jawa meyakini adanya zat tunggal (Hyang Widi) yang mutlak kekuasaannya, tetapi tidak dapat dijelaskan wujudnya. Keberadaan Tuhan justru tidak dapat diumpamakan dengan apapun dan siapapun, sebab bersifat beda daripada yang lainnya. Oleh karena berbeda, maka Ia tunggal, dan karena tunggal maka memiliki kekuasaan yang mutlak.

Keyakinan manusia Jawa akan keberadaan Tuhan tidak semata-mata diperoleh hanya melalui logika dan rasio semata, melainkan juga melalui rasa untuk memahami seluruh kebenaran yang ada. Baik tentang keberadaan alam semesta ciptaan Tuhan maupun keberadaan Tuhan Sang Maha Pencipta itu sendiri.

Keberadaan Tuhan yang disebutkan oleh manusia Jawa dengan tan kena kinaya gapa tersebut juga telah diterangkan oleh Imam (Al-Ghazali, 1982, p. 32) dalam bukunya yang berjudul Inti Sari Filsafat. Imam Al Ghazali menyebutkan bahwa keadaan Allah adalah sukar untuk dipahami oleh manusia umumnya. Akan tetapi, bagi mereka yang pandangan batinnya tajam dan mempunyai kekuatan gerak hati (ilham-intuisi-basirah-nafs) di dalam keadaan pikiran yang berimbang tidak pula dapat melihat atau mengetahui gerak kekuasaan Allah Yang Maha Kuasa. Orang-orang seperti itu (pandangan batinnya tajam dan mempunyai kekuatan gerak hati) pun tidak melihat langit sebagai langit, juga tidak melihat bumi sebagai bumi. Ia sebenarnya tidak melihat sesuatu yang di dalam alam semesta ini kecuali hanya cahaya dari wujud ciptaan Allah yang menembus seluruh alam semesta (Al-Ghazali, 1982, 
p. 32). Walaupun sukar untuk dipahami, namun kewujudan Allah yang digambarkan sebagai cahaya juga telah dijelaskan dalam Alquran (Surah an-Nur [24]: 35):

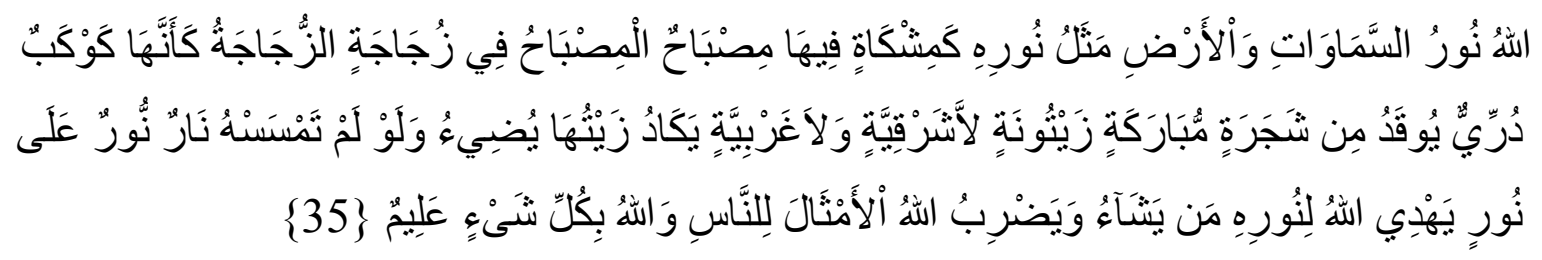

"Allah (pemberi) cahaya (kepada) langit dan bumi.Perumpamaan cahaya-Nya, seperti sebuah lubang yang tidak tembus, yang di dalamnya tidak ada pelita besar. Pelita itu di dalam tabung kaca, (dan) tabung kaca itu bagaikan bintang yang berkilauan, yang dinyalakan dengan minyak dari pohon yang diberkahi, (yaitu) pohon zaitun yang tumbuh tidak hanya di timur dan tidak pula di barat, yang minyaknya (saja) hampirhampir menerangi, walaupun tidak disentuh api. Cahaya di atas cahaya-Nya bagi orang yang Dia kehendaki, dan Allah membuat perumpamaan-perumpamaan bagi manusia. Dan Allah Maha Mengetahui segala sesuatu."

Keberadaan Tuhan merupakan sesuatu hal yang abstrak dan tidak dapat dibayangkan melalui logika semata. Bagaimana mungkin manusia mencoba mengartikan sesuatu yang besar dan tidak terbatas dengan akal dan pikiran manusia yang kecil dan terbatas ini. Sebaliknya untuk meyakinkan keberadaan Tuhan bagi manusia yang selalu berpusat pada logika semata, dapat dilakukan melalui sebuah analogi sederhana yaitu berdasarkan kejadiankejadian yang biasa dialami manusia dalam kehidupan sehari-hari.

Sebagai contoh manusia sering kali menginginkan sesuatu tetapi tidak memperoleh apa yang diinginkannya tersebut. Seperti pada contoh kasus, manusia ingin sehat tetapi sebaliknya mengalami sakit dan manusia ingin untung dalam berdagang tetap ijustru merugi. Dualisme yang dihadapi manusia antara sehat-sakit, untung-rugi, berhasil-gagal, senang-susah, suka-duka, dipuji-dicaci dan lainnya membuktikan bahwa manusia dapat berupaya untuk apa yang ingin diraihnya, tetapi tidak dapat memastikan hasil dari usaha tersebut secara mutlak. Ketidakmampuan manusia dalam memastikan hasil akhir setelah usaha tersebut membuktikan bahwa ada kekuasaan di luar manusia yang bersifat mutlak yang mengendalikan semua dualisme kehidupan yang akan dihadapi manusia.

Manusia juga sering kali tidak menginginkan sesuatu tetapi justru dengan cepat mendapatkan sesuatu tersebut. Sebaliknya, manusia juga seringkali menginginkan sesuatu dalam hidupnya tetapi tak kunjung mendapatkan. Seperti pada contoh kasus seorang Ibu yang tidak menginginkan punya anak lagi karena telah memiliki banyak anak, tetapi kemudian Ibu tersebut mendapatkan anak lagi. Contoh-contoh berdasarkan analogi tersebut membuktikan bahwa manusia bukanlah pemilik mutlak atas dirinya. Sebab jika manusia adalah pemilik mutlak atas dirinya, maka ia dapat mempertahankan, mewujudkan, dan mendapatkan apa saja yang menjadi keinginannya. Di situlah keberadaan Tuhan menjadi 
dipahami sebagai suatu zat mutlak yang sepenuhnya berbengaruh bagi keinginan kita, di mana terdapat dua kemungkinan terwujud ataupun tidak.

Manusia Jawa menyebutkan kemutlakan Tuhan dengan nama Gusti Allah Kang Murbeng Gesang yang berarti Allah (Tuhan) yang menguasai kehidupan dan juga Gusti Allah Kang Murbeng Dumadi yang bererti Allah (Tuhan) yang menguasai seluruh alam semesta. Kesadaran manusia Jawa bahwa Allah ialah Tuhan yang memiliki kekuasaan mutlak juga telah dinyatakan dalam Alquran (Surah al-Baqarah [2]: 255):

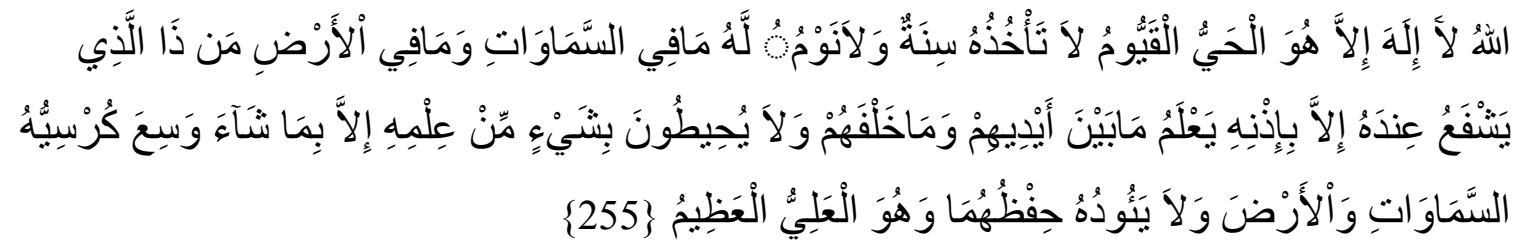

"Allah, tidak ada Tuhan selain Dia. Yang Maha Hidup. Yang terus menerus mengurus (makluk-Nya), tidak mengantuk dan tidak tidur. Milik-Nya apa yang ada di langit dan apa yang ada di bumi. Tidak ada yang dapat memberi syafaat di sisi-Nya tanpa izinNya. Dia mengetahui apa yang di hadapan mereka dan di belakang mereka, dan mereka tidak mengetahui sesuatu apa pun tentang ilmu-Nya melainkan apa yang Dia kehendaki. Kursi-Nya meliputi langit dan bumi.Dan Dia tidak merasa berat memelihara keduanya, dan Dia Maha Tinggi, Maha Besar."

Manusia Jawa juga menyadaribahwa Allah adalah Tuhan yang menguasai dan memelihara seluruh alam semestayang disebut dengan Gusti Allah Kang MurbengDumadi dalam falsafah Jawa. Hal tersebut selaras dengan ayat Al-Quran (Surah al-Fatihah [1]: 2):

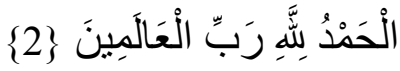

"Segala puji bagi Allah, Tuhan seluruh alam."

\section{Konsep Gusti Allah Orah Sare}

Gusti Allah orah sare berarti Allah (Tuhan) tidak tidur. Maksud tidak tidur yaitu Allah senantiasa terjaga di setiap masa. Keadaan terjaga berkenaan menjadikan Allah zat yang Maha Mengetahui segala perbuatan baik ataupun buruk telah, sedang, dan akan dilakukan manusia. Selain itu Allah juga Maha Mengetahui segala kejadian yang ada di alam semesta ini.

Falsafah Jawa juga kembali menegaskan konsep Gusti Allah orah sare dengan konsep Gusti Allah orah sare, pirsa satindak tanduk titahe manungsa yang berarti Allah tidak tidur, Ia mengetahui segala perilaku hambanya. 
Konsep Gusti Allah orah sareyang berarti Allah tidak pernah tidur dan selalu terjaga juga telah dijelaskan dalam ayat Alquran (Surah al-Baqarah [2]: 255):

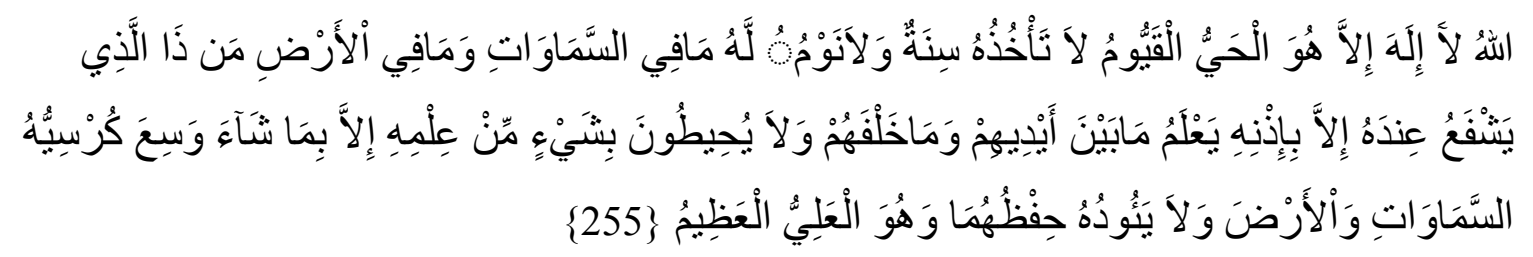

"Allah, tidak ada Tuhan selain Dia. Yang Maha Hidup.Yang terus menerus mengurus (makluk-Nya), tidak mengantuk dan tidak tidur. Milik-Nya apa yang ada di langit dan apa yang ada di bumi. Tidak ada yang dapat memberi syafaat di sisi-Nya tanpa izinNya. Dia mengetahui apa yang di hadapan mereka dan di belakang mereka, dan mereka tidak mengetahui sesuatu apa pun tentang ilmu-Nya melainkan apa yang Dia kehendaki. Kursi-Nya meliputi langit dan bumi.Dan Dia tidak merasa berat memelihara keduanya, dan Dia Maha Tinggi, Maha Besar."

Kesadaran akan kehadiran dan pengawasan Allah juga telah dinyatakan dalam Alquran (Surah al-Baqarah [2]: 115):

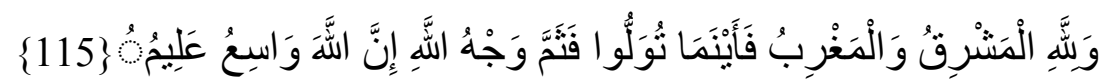

"Dan milik Allah timur dan barat. Ke mana pun kamu menghadap, di sanalah wajah Allah. Sungguh Allah yang Maha Luas, Maha Mengetahui."

Oleh karena itu, kesadaran manusia akan kehadiran Tuhan akan menimbulkan sikap untuk selalu berhati-hati dalam bertindak dan bertingkah laku. Sebab ia sadar sepenuhnya akan pengawasan Tuhan kapan pun dan dimana pun. Seterusnya, falsafah Jawa juga memiliki konsep Hyang Manon yang bererti Tuhan yang Maha Melihat. Segala tingkah laku manusia dapat dilihat oleh Tuhan. Kesadaran manusia Jawa bahwa Tuhan Maha Melihat, akan mencegah manusia dari perbuatan buruk meskipun sedikit saja.

\section{Konsep Sangkan Paran}

Sangkan paran secara harfiah berarti dari mana (sangkan) dan akan ke mana (paran), atau berarti sebuah konsep yang menanyakan dari mana (awal mula) dan akan ke mana (ujung) penciptaan seluruh isi alam semesta ini. Oleh karena itu, konsep sangkan paran dalam falsafah Jawa bertujuan untuk menanyakan awal dan akhir dari penciptaan seluruh isi di alam semesta ini. Konsep sangkan paran bertitik tolak dari kewujudan manusia dan alam semesta yang dapat dicapai melalui pancaindra. Konsep sangkan paran dalam falsafah Jawa dibagikan pada tiga hal yaitu:

a. Sangkan paraning dumadi yang berarti awal dan akhir dari penciptaan alam semesta.

b. Sangkan paraning manungsa yang berarti awal dan akhir dari penciptaan manusia. 
c. Sangkan paraning dumadining manungsa yang berarti awal dan akhir dari penciptaan alam semesta dan manusia.

Oleh karena itu, berdasarkan tiga hal di atas, maka dapat dipahami falsafah Jawa berkesimpulan bahwa Tuhan merupakan sangkan paraning dumadi (Tuhan merupakan awal dan akhir dari penciptaan alam semesta) dan Tuhan juga merupakan sangkan paraning manungsa (Tuhan merupakan awal dan akhir dari penciptaan manusia). Dapat diketahui bahwa Tuhan merupakan awal dan akhir dari penciptaanalam semesta dan manusia atau dalam falsafah Jawa disebut dengan sangkan paraning dumadining manungsa.

Falsafah Jawa telah memiliki pandangan bahwa awal penciptaan seluruh isi alam semesta termasuk juga manusia berasal dari Tuhan (sangkan) dan akhir penciptaan seluruh isi alam semesta akan kembali pada Tuhan (paran). Hal tersebut dapat mudah dipahami dengan maksud, awal berarti berasal dari Tuhan dan akhir berarti akan kembali pada Tuhan.

Konsep sangkan paran dalam falsafah Jawa juga telah membuktikan kepercayaan manusia Jawa terhadap keberadaan Tuhan. Adanya alam semesta dan seluruh isinya ini bukanlah sebuah kebetulan semata atau terjadi secara tiba-tiba dan tidak memiliki tujuan atas penciptaan tersebut. Melainkan alam semesta dan seluruh isinya ini berasal dari Tuhan Sang Pencipta alam semesta beserta seluruh isinya yang nantinya juga akan kembali kepada Tuhan sebagai Sang Pencipta.

Jika diteliti kembali, konsep sangkan paraning dumadi dan sangkan paraning manungsa menjelaskan bahwa tidak ada yang ada kecuali Tuhan semata dan tidak ada yang kekal kecuali Tuhan semata. Sebab sebagaimana yang telah dipaparkan di atas, bahwa manusia dan alam semesta yang berasal dari Tuhan, kelak akan kembali pada Tuhan.

Kesadaran manusia Jawa bahwa akhir penciptaan manusia dan alam semesta akan kembali pada Tuhan juga telah dinyatakan dalam Alquran (Surah al-Baqarah[2]:156):

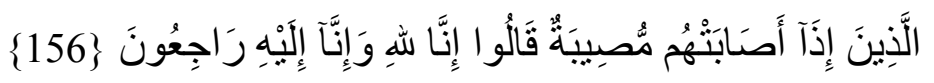

“... Sesungguhnya kami milik Allah dan kepada-Nya jualah kami kembali."

Pencarian manusia mengenai hakikat Tuhan akan berakhir dengan weruh (tahu atau mengerti) yaitu mengerti tentang sangkan paran atau awal dan akhir seluruh kejadian di muka bumi ini (Ciptoprawiro, 2000, p. 32).

\section{Kesimpulan}

Adanya kesinambungan antara (1) latar belakang Islamisasi di Nusantara, khususnya di Jawa melalui jalur kultural atau budaya oleh Wali Songo bersama raja-raja Jawa dan para pujangga Jawa, (2) ungkapan-ungkapan filosofis dalam falsafah Jawa sebagai bagian dari 
ciri khas karya sastra Jawa yang bersifat didaktis dan piwulang dalam karya sastra Jawa, yang disampaikan dalam bentuk ungkapan-ungkapan; renungan-renungan; berbentuk perlambangan dan kiasan yang dituliskan dalam karya sastra Jawa, dan (3) kesamaan antara hubungan harmonis manusia dengan Tuhan dalam konsep tri hita wacana dengan hubungan baik manusia dengan Tuhan (habluminallah) dalam ajaran Islam terkait konsep insan kamil, maka kajian ini ingin memaparkan adanya keterkaitan pemikiran Islam dalam falsafah Jawa dalam memahami konsep hakikat Tuhan, melahirkan pemikiran-pemikiran mengenai konsep hakikat Tuhan dalam falsafah Jawa yang selaras dengan pemikiran Islam. Dalam hal ini, pemikiran Islam dapat dilihat manakala terdapat kesamaan alur berpikir antara ungkapan-ungkapan filosofis Jawa dalam memahami konsep hakikat Tuhan dengan ayatayat yang terdapat dalam Alquran sebagai bagian ajaran dan nilai-nilai Islam.

Kesamaan alur berpikir antara ungkapan-ungkapan filosofis Jawa dalam falsafah Jawa dengan ajaran dan nilai-nilai Islam dalam ayat Alquran dalam memahami konsep hakikat Tuhan tersebut dapat dilihat pada:

1. Konsep Tan kena kinaya gapa yang berarti Tuhan tidak dapat dibayangkan keadaannya, mutlak kekuasaannya, tetapi tidak dapat dijelaskan wujudnya. Kesadaran manusia Jawa bahwa Allah ialah Tuhan yang memiliki kekuasaan mutlak selaras dengan ajaran Islam yang telah disebutkan dalam Alquran (Surah al-Baqarah [2]: 255). Dalam ajaran Islam yang dikemukakan oleh Imam Al-Ghazali terkait wujud Tuhan, diterangkan bahwa keadaan Allah adalah sukar untuk dipahami oleh manusia umumnya, namun kewujudan Allah yang digambarkan sebagai cahaya telah disebutkan dalam Alquran (Surah anNur [24]: 35). Falsafah Jawa menyebutkan kemutlakan Tuhan dalam memahami konsep tan kena kinaya gapa, juga dengan cara memahami konsep Gusti Allah Kang Murbeng Gesang yang berarti Allah (Tuhan) yang menguasai kehidupan dan juga Gusti Allah Kang Murbeng Dumadi yang berarti Allah (Tuhan) yang menguasai seluruh alam semesta. Kesadaran bahwa Allah adalah Tuhan yang menguasai dan memelihara seluruh alam semesta yang disebut dengan Gusti Allah Kang Murbeng Gesang dan Gusti Allah Kang Murbeng Dumadi dalam falsafah Jawa tersebut selaras dengan ajaran Islam yang telah disebutkan dalam ayat Alquran (Surah al-Fatihah [1]: 2).

2. Konsep Gusti Allah orah sare berarti Allah (Tuhan) tidak tidur. Maksud tidak tidur yaitu Allah senantiasa terjaga di setiap masa. Keadaan terjaga berkenaan menjadikan Allah zat yang Maha Mengetahui segala perbuatan baik ataupun buruk telah, sedang, dan akan dilakukan manusia. Selain itu Allah juga Maha Mengetahui segala kejadian yang ada di alam semesta ini. Falsafah Jawa juga kembali menegaskan konsep Gusti Allah orah sare dengan konsep Gusti Allah orah sare, pirsa satindak tanduk titahe manungsa yang berarti Allah tidak tidur. Ia mengetahui segala perilaku hambanya, ajaran tersebut selaras dengan ajaran Islam yang disebutkan dalam Alquran (Surah al-Baqarah [2]: 255). Berdasarkan 
pemahaman terhadap konsep Gusti Allah Orah Sare tersebut, maka menimbulkan sikap untuk selalu berhati-hati dalam bertindak dan bertingkah laku, dan sepenuhnya sadar akan pengawasan Tuhan kapan pun dan dimana pun. Kesadaran akan kehadiran dan pengawasan Allah terkait konsep Gusti Allah orah sare selaras dengan ajaran Islam yang disebutkan dalam Alquran (Surah al-Baqarah [2]: 115).

3. Konsep sangkan paran dalam falsafah Jawa bertujuan untuk menanyakan awal dan akhir dari penciptaan seluruh isi di alam semesta ini. Falsafah Jawa berkesimpulan bahwa Tuhan merupakan sangkan paraning dumadi (Tuhan merupakan awal dan akhir dari penciptaan alam semesta) dan Tuhan juga merupakan sangkan paraning manungsa (Tuhan merupakan awal dan akhir dari penciptaan manusia). Dapat diketahui bahwa Tuhan merupakan awal dan akhir dari penciptaan alam semesta dan manusia atau dalam falsafah Jawa disebut dengan sangkan paraning dumadining manungsa. Falsafah Jawa telah memiliki pandangan bahwa awal penciptaan seluruh isi alam semesta termasuk juga manusia berasal dari Tuhan (sangkan) dan akhir penciptaan seluruh isi alam semesta akan kembali pada Tuhan (paran). Hal tersebut dapat mudah dipahami dengan maksud, awal berarti berasal dari Tuhan dan akhir berarti akan kembali pada Tuhan. Kesadaran terkait konsep sangkan paran bahwa akhir penciptaan manusia dan alam semesta akan kembali pada Tuhan selaras dengan ajaran Islam yang telah disebutkan dalam Alquran (Surah al-Baqarah[2]: 156).

\section{Referensi}

Al-Ghazali. (1982). Inti sari Filsafat. Singapura: Pustaka Nasional PTELTD Singapura.

Azra, A. (2002). Jaringan Global dan Lokal Islam Nusantara. Bandung: Mizan.

Ciptoprawiro, A. (2000). Filsafat Jawa. Jakarta: Balai Pustaka.

Departemen Agama Republik Indonesia. (n.d.). Al-Qur'an Tajwid dan Terjemah. Khairul Bayaan (Yayasan Penyelenggara Penerjemah / Penafsir Al-Qur'an Revisi Terjemah).

Departemen Pendidikan dan Kebudayaan. (1991). Kamus Besar Bahasa Indonesia (Edisi Kedua). Jakarta: Balai Pustaka.

Endraswara, S. (2012). Filsafat Sastra. Yogyakarta: Layar Kata.

Endraswara, S. (2013). Filsafat Ilmu (Konsep, Sejarah, dan Pengembangan Metode Ilmiah. Yogyakarta: Caps.

Munarsih. (2007). Serat Wulang Putri. Yogyakarta: Panji Pustaka.

Mustakim. (2005). Gresik:Sejarah Bandar Dagang dan Jejak Awal Islam. Jakarta: CV. Citra Unggul Laksana.

Pasha, L. (2011). Butir-Butir Kearifan Jawa. Yogyakarta: IN AzNa Books. 
Quswandhi, M. D. (2008). Waliyah Zainab Putri Pewaris Syeikh Sitti Jenar-Sejarah Agama dan Peradaban di Pulau Bawean. Bawean: Yayasan Waliyah Zainab Diponggo.

Salam, S. (1960). Sekitar Wali Sanga. Kudus: Menara Kudus.

Sunardi. (1993). Arjuna Wiwaha. Jakarta: Balai Pustaka.

Sunyoto, A. (2012). Atlas Wali Songo (Buku Pertama yang Mengungkap Wali Songo sebagai Fakta Sejarah). Depok: Pustaka Iman. 
